\title{
A persistent infection in MDCK cells by an influenza type $B$ virus
}

\author{
Anaira C. Clavo, Hunein F. Maassab and Michael W. Shaw \\ Department of Epidemiology, University of Michigan, Ann Arbor, MI 48109, USA
}

(Received 19 November 1992; revision received and accepted 1 February 1993)

\section{Summary}

A persistent infection in Madin Darby Canine Kidney (MDCK) cells by an influenza $B$ virus (B/Tecumseh/63/80) has been established and characterized. Virus recovered from the persistent state titrated lower in relation to the parental wild-type ( $w t)$ that initiated the infection as measured by hemagglutination and egg and tissue culture infectious dose, suggesting that the virus is a less cytopathic variant of the original $w t$ virus. The persistent virus $(p v)$ has decreased cytopathology for both MDCK and primary chick kidney (PCK) cell lines, and exhibits different RNA and protein electrophoretic migrations. Plaques of the persistent virus are smaller and take longer to appear, indicating that the $p v$ is a slower growing variant of the $w t$. The small plaque mutant phenotype may play a role in the maintenance of the persistent infection in MDCK cells. The $p v$ differs from the $w t$ antigenically and in its ability to form deposits of uric acid-like crystals beneath the culture monolayers.

Persistent infection; Madin Darby canine kidney; Influenza type B virus; Uric acid; Gout

Persistent infections are most often mediated by a variety of mechanisms which may come into play at different times post-infection, but, in general for viruses to persist in vitro, it is necessary for virus production to somehow be reduced. In vivo,

Correspondence to: H.F. Maassab, Dept. of Epidemiology, School of Public Health, University of Michigan, 109 Observatory, Ann Arbor, MI 48109, USA. 
the immune system must also be avoided (reviewed in Oldstone, 1991). In this report we describe the results of studies on a stable persistent infection in a continuous cell line (MDCK) by an influenza virus (B/Tecumseh/63/80) established in our laboratory. The persistently infected ( $p i$ ) cell line has been propagated for several years and the cultures continue to produce low levels of infectious virus. The $p i$ cultures display a unique characteristic in the production of crystalline deposits of uric acid underneath the cell monolayers.

The $p i$ cell line was originally established in February, 1982, by infecting MDCK cells at low MOI ( $<1$ PFU per cell) with influenza B/Tecumseh /63/80 virus and feeding the surviving cells until confluency was reattained. A similar attempt using influenza A/Ann Arbor/2/85 (H3N2) virus was unsuccessful. The pi cultures have since been maintained at $35^{\circ} \mathrm{C}$ with biweekly feedings by replacing $50 \%$ of the growth media. Passage numbers 30 and 31 were used in the present study. Temperature sensitivity of the persistent virus has not been analyzed although an attempt to 'cure' the infection by incubation at $39^{\circ} \mathrm{C}$ was unsuccessful. Other continuous cell lines have not been tested for the ability to establish a persistent infection.

Antigenic analysis by hemagglutination inhibition (HI) of the persistent virus using a variety of sera has confirmed its identity as an influenza type B virus. There was no crossreactivity with influenza types A or C viruses, but a low level cross-reactivity between the $w t$ and $p i$ viruses was observed, suggesting that a mutation event occurred that altered the antigenicity of these viruses. The persistent virus $(p v)$ titrates lower than the parental $w t$ by hemagglutination, tissue culture infectivity and egg infectious dose and has a decreased cytopathogenicity for MDCK and PCK cell lines. However, persistently infected cells periodically entered cycles of crisis with a concomitant increase in cytopathology.

Titers at different times for the $w t$ and the $p v$ are shown in Table 1. Since $\mathrm{PFU} / \mathrm{ml}$ could not be obtained routinely for the persistent virus, all virus stocks were diluted to obtain 16 hemagglutinating units (HAU) before infecting MDCK cells ( $1 \mathrm{ml}$ inoculum per $8 \times 10^{5}$ cells in 24-well plates). Virus production was followed by sampling the media at different times following infection. The $w t$ virus replicated to high titer and tested positive in all systems used, whereas the $p v$ could not be detected by plaque formation in its host cell although it could be detected by the other three assays. The results presented in Table 1 are from the third egg passage of the $p i$ virus which showed no plaques at a $10^{-1}$ dilution using $0.1 \mathrm{ml}$ per well $\left(<100 \mathrm{PFU}\right.$ per $\mathrm{ml}$ ). When lower dilutions (i.e., $1.0 \mathrm{ml}$ of $10^{-1}$ dilution) or later egg passages were used, small numbers of plaques were seen that could be scored.

The $w t$ virus is able to produce a lytic infection that destroys all the cells by the second day post-infection, while the pi cultures continually produce low levels of virus which is capable of establishing persistent infections in new MDCK cultures. The $p v$ is also a slower growing variant of the $w t$ and exhibits a small-plaque mutant phenotype on MDCK and PCK cell lines. The combination of decreased cytopathogenicity and slow-growth/small-plaque mutant phenotypes probably accounts for and/or plays an important role in the maintenance of the persistent 


\section{TABLE 1}

Comparison of different titers of B/Tecumseh $/ 63 / 80$ wild-type and persistent viruses at $35^{\circ} \mathrm{C}$

Wild-type virus and $p v$ were used in this study. Samples of supernatant medium were collected every $24 \mathrm{~h}$ and stored at $-70^{\circ} \mathrm{C}$ until assayed for infectious virus and hemagglutinating properties. $\mathrm{HAU} / \mathrm{ml}$, hemagglutinating units per $0.025 \mathrm{ml}$ using $0.5 \%$ chicken erythrocytes; EID ${ }_{50}$, egg infectious dose per $\mathrm{ml}$; PU $/ \mathrm{ml}$, plaque-forming units per $\mathrm{ml}$ of virus recovered from the supernatant medium when assayed on MDCK monolayers at $37^{\circ} \mathrm{C}$; $\mathrm{TCID}_{50}$, tissue culture infectious dose per ml; ND, monolayer was destroyed.

\begin{tabular}{|c|c|c|}
\hline & \multicolumn{2}{|c|}{ B/Tecumseh /63/80 } \\
\hline & wild-type virus & persistent virus \\
\hline \multicolumn{3}{|l|}{ Day 1} \\
\hline $\mathrm{HAU} / \mathrm{ml}$ & 128 & 64 \\
\hline $\mathrm{EID}_{50}$ & $3.16 \times 10^{8}$ & $1 \times 10^{4}$ \\
\hline $\mathrm{PFU} / \mathrm{ml}$ & $7.5 \times 10^{7}$ & $<100$ \\
\hline $\mathrm{TCID}_{50}$ & $6 \times 10^{7}$ & $1.41 \times 10^{5}$ \\
\hline \multicolumn{3}{|l|}{ Day 2} \\
\hline $\mathrm{HAU} / \mathrm{ml}$ & 256 & 128 \\
\hline $\mathrm{EID}_{50}$ & $2.08 \times 10^{8}$ & $1 \times 10^{4}$ \\
\hline $\mathrm{PFU} / \mathrm{ml}$ & $1 \times 10^{8}$ & $<100$ \\
\hline $\mathrm{TCID}_{50}$ & $3.09 \times 10^{5}$ & $1 \times 10^{4}$ \\
\hline \multicolumn{3}{|l|}{ Day 3} \\
\hline $\mathrm{HAU} / \mathrm{ml}$ & ND & 128 \\
\hline $\mathrm{EID}_{50}$ & ND & $1 \times 10^{4}$ \\
\hline $\mathrm{PFU} / \mathrm{ml}$ & ND & $<100$ \\
\hline $\mathrm{TCID}_{50}$ & ND & $1 \times 10^{4}$ \\
\hline \multicolumn{3}{|l|}{ Day 4} \\
\hline $\mathrm{HAU} / \mathrm{ml}$ & ND & 64 \\
\hline $\mathrm{EID}_{50}$ & ND & $1 \times 10^{4}$ \\
\hline $\mathrm{PFU} / \mathrm{ml}$ & ND & $<100$ \\
\hline $\mathrm{TCID}_{50}$ & ND & $1 \times 10^{4}$ \\
\hline \multicolumn{3}{|l|}{ Day 5} \\
\hline $\mathrm{HAU} / \mathrm{ml}$ & ND & 64 \\
\hline $\mathrm{EID}_{50}$ & ND & $1 \times 10^{2}$ \\
\hline $\mathrm{PFU} / \mathrm{ml}$ & ND & $<100$ \\
\hline $\mathrm{TCID}_{50}$ & ND & $<200$ \\
\hline
\end{tabular}

infection by this influenza type $B$ virus in MDCK cells. When immune serum was introduced into the medium of confluent monolayers of persistently infected cells for a period of 9 weeks, it failed to cure the infection since virus shedding resumed after its removal with a titer comparable to that seen prior to the introduction of immune serum. This suggests that the $p v$ does not persist in MDCK cells by cyclic reinfection of susceptible cells by virus present in the culture medium (carrier culture).

Molecular characterization of the viruses showed that mutations are apparent in most of the gene segments of the $p v$ when compared to the $w t$ (Fig. 1). All 8 gene segments are defined for the $w t$, while the RNA segments from the $p v$ migrated at 


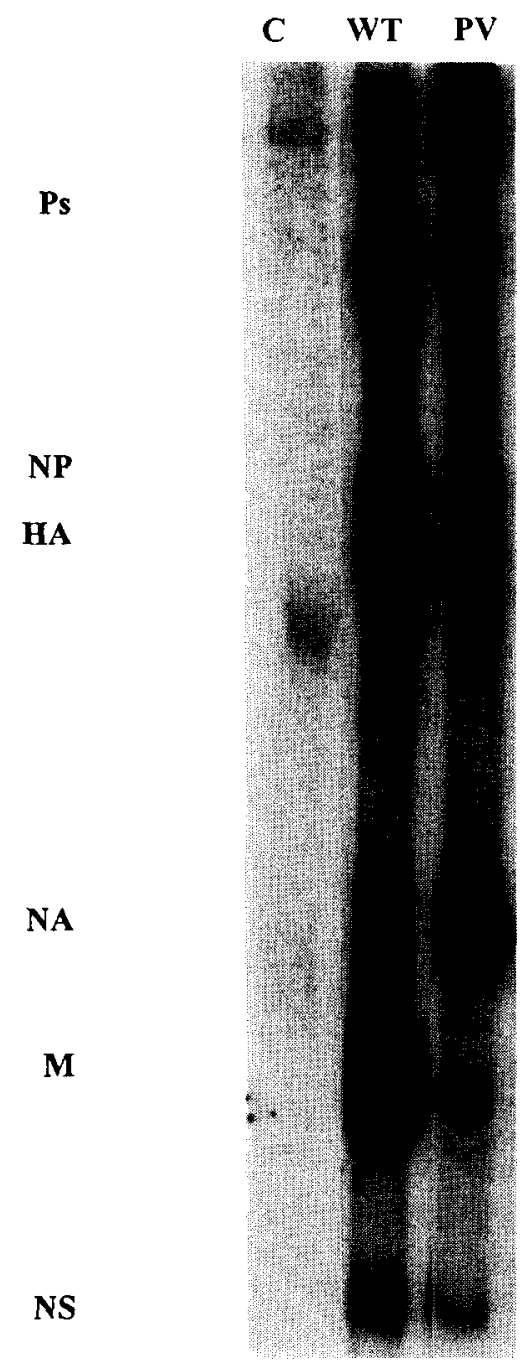

Fig. 1 RNA polyacrylamide gel electrophoresis of $B$ /Tecumseh/63/80 wild-type and persistent viruses. The $p v$ and $w t$ viruses were labeled with $\left[{ }^{32} \mathrm{P}\right]$. The culture medium was collected for clarification, vRNA was pelleted through a $30 \%$ sucrose cushion, and treated with proteinase $\mathrm{K}$ and SDS. The RNA was ethanol-precipitated, dissolved in loading buffer at 150,000 to $200,000 \mathrm{cpm}$ per sample, and loaded onto $3 \%$ acrylamide: $0.15 \%$ Bis: $0.6 \%$ agarose and run at $240 \mathrm{~V}$ for $21 \mathrm{~h}$ at $34^{\circ} \mathrm{C}$. C, mock-infected MDCK cells; WT, wt virus; PV, $p v$ virus; Ps, polymerases; HA, hemagglutinin; NP, nucleoprotein; NA, neuraminidase; $M$, matrix and NS, non-structural genes.

different positions, making gene assignment difficult. Because of the difficulties encountered in growing sufficient persistent virus for analysis, the relative molar ratios of the RNA species detected has not been determined. The data obtained do not eliminate the possible presence of DI particles in the virus population; 


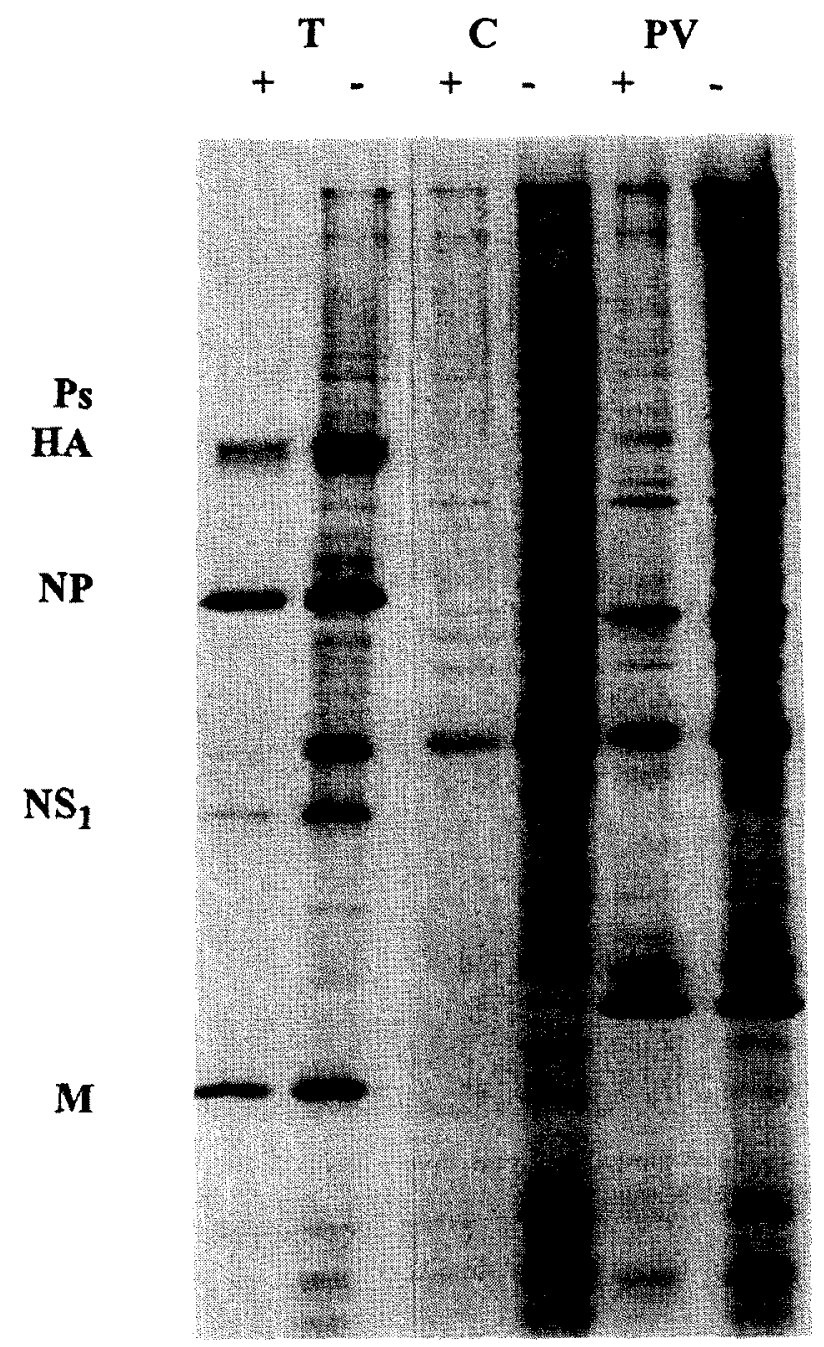

Fig. 2. Infected cell polypeptide profiles of $B / T e c u m s e h / 63 / 80$ wild-type and persistent viruses. The $p v$ and $w t$ viruses were adsorbed onto 7-day-old PCK monolayers grown in 6-well plates for $1.5 \mathrm{~h}$ at room temperature (RT). Serum-free media was added and cultures were incubated for $6 \mathrm{~h}$ at $35^{\circ} \mathrm{C}$; then replaced by $600 \mu l$ of media containing $\left[{ }^{35} S\right]$ methionine $(120 \mu \mathrm{Ci}$ per well) and incubated $45 \mathrm{~min}$ as above. The label was removed, the monolayers were washed with cold PBS and lysed directly in cell lysis buffer. After sonication, cell lysates were loaded onto $13 \%$ acrylamide: $0.0625 \%$ Bis, $4 \mathrm{M}$ urea gels and run at RT. T, wt; C, mock-infected cells; PV, pv; Ps, polymerases; HA, hemagglutinin; NA, neuraminidase; $\mathrm{NP}$, nucleoprotein; $\mathrm{NS}_{1}$ ), non-structural and $\mathrm{M}$, matrix proteins. Use $(+)$ or omission $(-)$ of $150 \mathrm{mM} \mathrm{NaCl}$ to inhibit host cell protein synthesis (Lamb et al., 1978).

however, the PFU/HA ration for the pv did not change after several egg passages, which argues against their presence.

Protein profiles are also different for these two virus lines (Fig. 2). There is evidence of change in every identifiable protein produced by the persistent virus 
Fig. 3. Light micrographs of normal and persistently infected cells. Upper panel, uninfected MDCK cells showing dome or blister formation; lower panel, $p i$ cells showing crystal production. Final magnification of $200 \times$ for both panels.

with apparent deletions in the NP and $\mathrm{NS}_{1}$ genes and a suppression in the expression of the $\mathbf{M}$ gene. The same migration patterns for the genes and proteins produced by the $p v$ were seen in MDCK and PCK cells using a variety of gel systems (data not shown), thus confirming the virus-specificity of the changes.

The $p i$ cell line displays an unusual characteristic that consistently appears about 5-12 weeks after cultivation, resulting in the production of a crystalline precipitate that deposits between the serosal surface of the cells and the supporting substrate. The crystal formation is also seen when new pi cultures are established by infection with virus from other $p i$ cultures usually becoming detectable after 3-4 months. This property has not been documented in any other persistent infection. Under light microscopy, the crystals have the appearance of an amorphous refringent substance (Fig. 3), but under the electron microscope they have a characteristic needle-shaped form (Fig. 4). The general characteristics of the crystals are outlined in Table 2. 


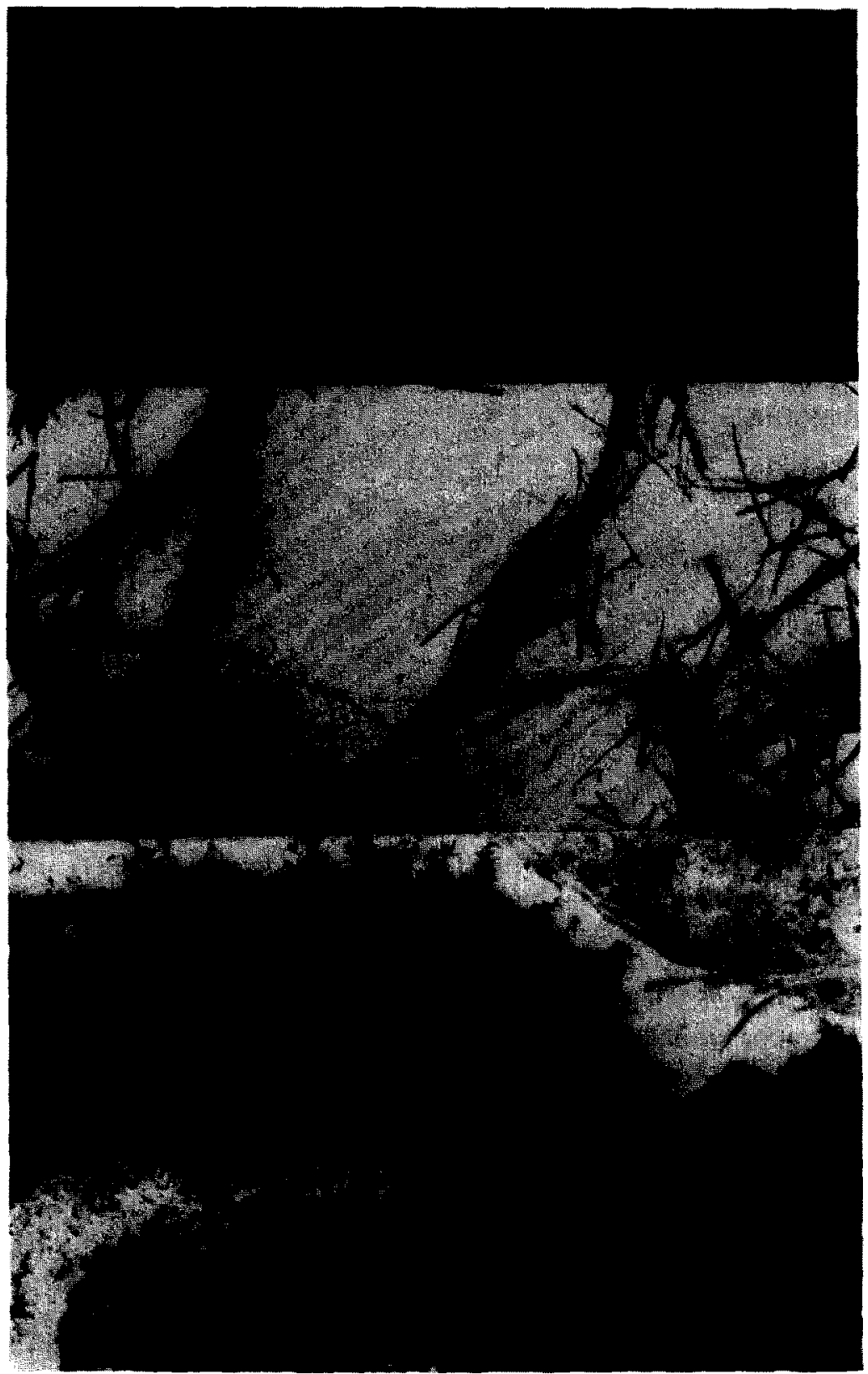

Fig. 4. Electron micrographs of natural and synthetic crystals. Natural crystals were scraped from tissue culture flasks, washed in $\mathrm{dsH}_{2} \mathrm{O}$, rinsed in ethanol, dried, and placed on formvar-coated grids (upper panel; final mag. $40,000 \times$ ). Synthetic monosodium urate (MSU) crystals were synthesized (Denko and Whitehouse, 1976) and observed on formvar-coated grids (center panel; final mag. 40,000 $\times$ ). Natural crystals as they deposit between the serosal surface of the cells and the tissue culture flask (lower panel; final mag. $266,000 \times$ ). 
TABLE 2

Properties of the crystalline structure

Several characteristics of the crystalline structure produced by the pi cell line in comparison to synthetic monosodium urate (MSU) crystals and powdered uric acid (UA). Solubility of the natural and synthetic crystals, and of uric acid, was tested in $\mathrm{HCl}$ and $\mathrm{NaOH}$. The shapes of the crystals were identified. A Bio-Rad HP-87 organic column in series with a Bio-Rad $5 \mu \mathrm{m}, 15 \mathrm{~cm}$, ODS reverse phase column was used for the HPLC studies and The Central Pathology Laboratory (Santa Rosa, CA) Library Search Program was used for peak identification. TLC on silica gel used butanol, acetic acid and water as the solvent system and $I_{2}$ was used for analyte detection. An HP-5995B quadrapole $\mathrm{GC} / \mathrm{MS}$ system was used for analysis.

\begin{tabular}{llll}
\hline & $\begin{array}{l}\text { Natural } \\
\text { (from TC) }\end{array}$ & $\begin{array}{l}\text { Synthetic } \\
\text { (MSU) }\end{array}$ & $\begin{array}{l}\text { Uric acid } \\
\text { (powder) }\end{array}$ \\
\hline $\begin{array}{l}\text { Solubility in } \mathrm{HCl} \\
\text { Solubility in } \mathrm{NaOH}\end{array}$ & + & - & - \\
Shape: & - & + & + \\
$\quad \mathrm{EM}$ & needles & needles & $\mathrm{n} / \mathrm{a}$ \\
$\quad$ Light $\mathrm{HCl}$ p & $\mathrm{n} / \mathrm{a}$ & needles & $\mathrm{n} / \mathrm{a}$ \\
$\quad$ crystals & $\mathrm{n} / \mathrm{a}$ & $\mathrm{n} / \mathrm{a}$ \\
$\quad$ Loss of birefringency at $60^{\circ} \mathrm{C}$ & + & & - \\
Melting point at $370^{\circ} \mathrm{C}$ & - & & - \\
HPLC $($ UA by program) & + & & + \\
GC/MS peaks & - & & - \\
TLC on silica gel: & & & + \\
2 spots, Rf of 0.67 and 0.30 (UA) & + & & + \\
\hline
\end{tabular}

The crystals adhere strongly to plastic tissue culture flasks and are soluble in 1 $\mathrm{N}$ hydrochloric acid $(\mathrm{HCl})$ but not in $1 \mathrm{~N}$ sodium hydroxide $(\mathrm{NaOH})$, indicating a basic rather than acidic crystal, possibly due to a basic salt in the growth media. These crystals have tentatively been identified as uric acid by high performance liquid chromatography (HPLC) using the Central Pathology Laboratory (Santa Rosa, CA) Library Search Program and by thin layer chromatography (TLC) using iodine $\left(\mathrm{I}_{2}\right)$ vapor for analyte detection. HPLC studies of the unknown crystals were performed by dissolving them in $1 \mathrm{~N} \mathrm{HCl}$. The residue lost its birefringence at $60^{\circ} \mathrm{C}$ but the solid did not melt by $370^{\circ} \mathrm{C}$; authentic uric acid neither melts nor loses its birefringency by $370^{\circ} \mathrm{C}$. Cells included as controls did not yield a residue from the $1 \mathrm{~N} \mathrm{HCl}$ wash. A large peak at 17.9 min was present in the chromatogram and was identified as uric acid based upon maximum retention time, UV spectrum and the first derivative ultraviolet (UV) spectrum. TLC (silica gel using butanol, acetic acid and water as solvent system) of the $\mathrm{HCl}$ solution yielded two spots; $\mathrm{Rf}$ 0.67 and 0.30 . An $\mathrm{HCl}$ solution of authentic uric acid yielded the same spots. Both unknown and uric acid solutions showed no peaks upon gas chromatography and mass spectrophotometry (GC/MS) analysis.

Monosodium urate (MSU) crystals were synthesized (Denko and Whitehouse, 1976) to compare their structure with the natural crystals recovered from the pi. It was found that both crystals were very similar by electron microscopy, resembling acicular (needle-shaped) rods, but synthetic crystals were much larger than the 
ones from the pi cultures (Fig. 4). In addition, disorptive chemical ionization (DCI) studies have shown that the general pattern of ionization for both crystals is very similar to that of uric acid (data not shown).

The likely urate nature of the crystals was further supported by a reduction in crystal production seen when the persistent cultures were treated with normal human therapeutic doses $(25 \mu \mathrm{g} / \mathrm{ml})$ of allopurinol, a drug used in the treatment of hyperuricemia and gout to reduce uric acid production and its levels in plasma and urine. A pi culture producing the crystalline deposit was treated with the drug for two months with an identical untreated pi culture used as control. Crystal deposit was monitored by marking areas containing the crystalline structures which were visually evaluated for increase in size. Crystal formation continued in the untreated cultures while it decreased in the treated ones.

Gout is a metabolic disorder characterized by an abnormal purine metabolism, excess uric acid in the blood, attacks of acute arthritis and the production of tophaceous deposits in the cartilages of the joints, mostly urates. The etiology of the hyperuricemia and the resultant deposit of MSU in joints and kidneys is the result of an overproduction of uric acid and the patient's inability to excrete it. Uric acid metabolism may be perturbed in cells infected with this persistent influenza type B virus because of the accumulation of viral materials such as nucleic acids and/or proteins. Alternatively, the virus may somehow alter the purine metabolic pathways, resulting in increased production of urate by direct action of its gene products. It is conceivable that this system might be used as an in vitro model for the study of gout or to clarify the role of influenza virus in purine metabolism and its possible relation to human disease.

Several cell culture models for hyperuricemia, using murine T-cell lymphomas, have been studied based on inosinic acid (IMP) dehydrogenase-deficient mutants, such as deficiencies in adenylosuccinate synthetase (Ullman, 1984) and hypoxanthine/guanine phosphoribosyl transferase (Chinault and Caskey, 1984). In these types of deficiencies, the cell increases intracellular IMP in an attempt to maintain ATP levels. Other studies have been attempted to cause hyperuricemia in vivo by administering high doses of uric acid to various animal species (e.g., dog, rabbit, rat), but the high liver uricase levels present in these species prevented sustained hyperuriccmia (Bluestone ct al., 1975; Stavric and Nera, 1978).

An in vitro system to evaluate the morphological and functional interactions between renal epithelial cells and urates has also been reported (Emmerson et al., 1989, 1990). Addition of crystals to monolayer cultures of MDCK cells leads to the formation of reaction sites which consist of blister-like structures. Crystals were apparent by transmission and scanning electron microscopy inside the cells, in vacuoles containing lysosomal enzymes, and within intercellular spaces, indicating that some of them had passed through the epithelial monolayer.

Recently, it has been shown that influenza A virus from waterfowl is able to replicate in several organs when the virus is inoculated intravenously (i.v.) into chickens (Slemons et al., 1990, 1991). A wide tissue tropism after i.v. inoculation of the virus was found but there was a general predilection for kidney and digestive tract tissues (Condobery and Slemons, 1992). Urates were found in the pericardial 
sac and on the surface of the liver when postmortem lesions were examined, and microscopic lesions present in kidneys were consistent with visceral gout.

Based on the fact that many cell systems have aberrant membrane ion channel activities leading to disease (e.g., cystic fibrosis, gout, and kidney stones), the production of uric acid or a salt of an urate nature by a kidney cell line suggested a possible mutation in a gene regulating or encoding an ion channel could have been affected. The $p v$ gene segments are currently being sequenced and compared to the parental line. An obvious candidate for the gene responsible is the NA/NB gene of the virus because of the structural similarities between NB and the $M_{2}$ protein of influenza $A$ virus which has been postulated to form a selective membrane ion channel (Sugrue and Hay, 1991).

Information obtained from the study of persistent infections may be helpful in determining the roles of viruses in chronic diseases and in the study of the nature of viral pathogenesis in vivo. The persistence of an influenza virus in a continuous cell line may also provide insight in how viruses evolve from a lytic state to persist in their hosts and the consequences of this action to the emergence of the chronic state.

\section{Acknowledgements}

The authors wish to thank Dr. Jess G. Thoene for providing HPLC and TLC analysis of the crystalline product. This research was submitted as partial fulfillment of the requirements for the degree of Doctor of Philosophy of A.C.C.

\section{References}

Bluestone, R., Brady, S., Waisman, J. and Klinenberg, J.R. (1975) Experimental hyperuricemic nephropathy. Arthritis and Rheum. 18, 823-834.

Chinault, A.C. and Caskey, C.T. (1984) The hypoxanthine phosphoribosyltransferase gene: a model for the study of mutation in mammalian cells. Prog. Nucl. Acid Res. Mol. Biol. 31, 295-313.

Condobery, P.K. and Slemons, R.D. (1992) Biological properties of waterfowl-origin type A influenza viruses in chickens. Avian Dis. 36, 17-23.

Denko, C.W. and Whitehouse, M.W. (1976) Experimental inflammation induced by naturally occurring microcrystalline calcium salts. J. Rheumatol. 3, 54-62.

Emmerson, B.T., Cross, M., Osborne, J.M. and Axelsen, R.A (1990) Reaction of MDCK cells to crystals of monosodium urate monohydrate and uric acid. Kidney Int. 37, 36-43.

Emmerson, B.T., Axelsen, R. and Cross, M. (1989) A model of gout nephropathy. Adv. Exp. Med. Biol. 253, 205-209.

Lamb, R.A., Etkind, P.R. and Choppin, P.W. (1978) Evidence for a ninth influenza viral polypeptide. Virology $91,60-78$.

Oldstonc, M.B.A. (1991) Molecular anatomy of viral persistence. J. Virol. 65, 6831-6836.

Slemons, R.D, Condobery, P.K. and Swayne, D.E. (1991) Assessing pathogenicity potential of waterfowl-origin type A influenza viruses in chickens. Avian Dis. 35, 210-215.

Slemons, R.D., Locke, N.L., Sheerar, M.G., Duncan, R.M., Hinshaw, V.S. and Easterday, B.C. (1990) Kidney lesions associated with mortality with waterfowl influenza viruses. Avian Dis. 34, 120-128. 
Stavric, B. and Nera, E.A. (1978) Use of the uricase-inhibited rat as an animal model in toxicology. Clin. Toxicol. 13, 47-74.

Sugrue, R.J. and Hay, A.J. (1991). Structural characteristics of the $\mathbf{M}_{2}$ protein of influenza A viruses: evidence that it forms a tetrameric channel. Virology 180, 617-624.

Ullman, B. (1984) IMP dehydrogenase mutants: cell culture model for hyperuricemia. Adv. Exp. Med. Biol. 165, 373-379. 